others in many countries. He was appointed assistant director of the then Bureau of Entomology in 1913, and filled that position until July 1942, when be succeeded Sir Guy Marshall as director of the present Institute. Dr. Neave's name is inseparably associated with the growth and outstanding reputation of the Institute's Publication : Office. In particular the Review of Applied Entomology and the Nomenclator Zoologicus (in four volumes) are constant reminders of the debt which not only entomologists but also general zoologists owe to Dr. Neave. In addition, during the four years he was director of the Institute, Dr. Neave supervised the production of the bulky "Insecta" part of the annual Zoological Record, besides editing the Bulletin of Entomological Research. $\mathrm{He}$ carries with him the good wishes of a wide circle of entomologists, and many others, on his retirement. $\mathrm{He}$ is succeeded as director of the Imperial Institute of Entomology by Dr. W. J. Hall, who was appointed assisł dint director in 1944 (see Nature, 153, 649 ; 1944). Astronomical Institutelat Amsterdam :

THE Astrongrfief Institute of the University of Amsterdam haf anique reputation in the astronomical world af $D$ centre for research in both stellar physies and pllar statistics. This is due to the work of its fir director, Prof. A. Pannekoek, whose retifment has just been announced (Nature, Nov. 9, p. 667\%. Noteworthy among his investigations was that hich first established a wide dispersion in the absolute magnitudes of the hot, $B$-type stars, and so led to the now generally accepted view of the existence of these stars in highly localized clusters. Equally significant was his work on Saha's theory of thermal ionization and on the theory of stellar line contours. $\mathrm{He}$ is one of the three pioneers-McCrea and Unsöld being the others-responsible for developing a wholly deductive theory of the model stellar atmosphere, while his more recent spectroscopic work on the brighter Cepheids has already led to interesting developments in spectrophotometric technique.
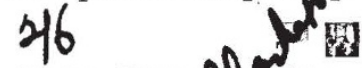

Prof. H. Zanstra

Prof. PANNfHer's successor as director of the Institute is $\mathrm{Prd} \mathrm{H}$. Zanstra, well known in Great Britain as the first Radeliffe Travelling Fellow in astronomy I Zanstra's work has been inspired by a keer physeal insight, and has led to the widely acce folquantitative theory of the luminosity of the gasedus nebulæ. Equally significant have been his investigations of the dynamics of radiation pressure in diffuse and planetary nebulæ, and his discussion of the probable expansion of the latter objects. In recent years his interest has been awakened in solar physics, and be has been responsible for investigations on the hydrodynamies of solar prominences and the polarization of resonance radiation from the limb of the sun. In Prof. Zanstra the Institute has a director who gay be expected to maintain its great reputation.

\section{Fourth Centenary of the Birth of Tycho Brahe}

The Rev. PrAntonio Due Rojo, S.J., has an article witho title, "En El Quarto Centenario Del Nacimifto de Tycho-Brahe" in Euclides of January 1946, N\$. 59, which. briefly outlines the main features if the astronomical work of Tycho Brahe. As a pyectical astronomer, Tycho realized that the question of the true system of the world could be settled only by amassing evidence from the positions and motions of the planets. His long series of observations made possible the discovery of Kepler's laws of planetary motion and also the final proof of the heliocentric theory-a theory which Tycho himself had rejected. The author refers to his relations with astrology, and mentions one of his books which was published after his death, with the expressive title, "Tychonis Brahe de disciplinis mathematicis oratio, in qua simul astrologia defenditur et ab objectionibus dissentientium vindicatur". A similar vindication of astrology was the subject of one of his conferences in the University of Copenhagen, and his position at the Court required an annual compilation of prognostications for the year following as well as horoscopes of each member of the royal family. It is interesting to know that the foundation stone of Uraniborg was laid on August 8, 1576, at a time when Jupiter and Regulus were in conjunction and the moon was in Aquarius, that is, when the celestial influences were most favourable. Whatever may have been the real views of some eminent astronomers on the subject, necessity sometimes compelled them to cast horoscopes as a means of livelihood. A well-known instance of this is seen in the case of Kepler, who cast horoscopes for princes and other important people. Probably astrologers in those days were able to ease their consciences by quoting the saying of the classical poet, "Mundus vult decipi : ergo decipiatur". In spite of his astrological practices, Tycho stands before the world as a renowned astronomer and an example of what can be accomplished by patient and persistent observation.

\section{University Grants Committee}

Sir Rober/Greig and Sir Henry Tizard have resigned from the University Grants Committee. The Chanceller of the Exchequer has appointed the following new members: Miss D. Dymond, principal of Pprtsmouth Training College; Mr. H. L. Elvin, proncipal of Ruskin College, Oxford; Mr. H. S. Magnay, director of education, Liverpool ; and Prof. E. K. Rideal, director of the Davy Faraday Laboratory, Royal Institution. These appointments broaden the membership of the committee by going outside the strictly academic field of university education.

\section{Commonwealth Travelling Fellowship for the Royal College of Surgeons}

A prominent New Zealand industrialist has made an anonymous gift to the Royal College of Surgeons of Englayd for the endowment of a Commonwealth Travelligg Professorship. The endowment will provide an income of about $£ 2,000$ a year, and the benefaction/is to be known as a gift from "A New Zedand Family". A Commonwealth professor will be appointed each year and will generally be a prominent physician, surgeon or scientific worker resident in Great Britain or in Australia or New Zealand. The appointing authorities are also empowered, however, to elect as a professor a distinguished teacher from one of the other Dominions. The professor will be required to travel from the country where he or she is ordinarily resident to Great Britain, or to Australia and New Zealand, and to any other Dominion of the British Commonwealth, for the purpose of assisting in the advancement of medical science either by lecturing, teaching or engaging in research. It is hoped that the institution of this professorship. will not only lead to the establishment 